\title{
Women on Walls: The Female Subject in Modern Graffiti Art
}

\author{
Katja Fleischmann
}

James Cook University Australia

Robert H. Mann

Writer

\begin{abstract}
Modern day wall art featuring women as subjects is usually painted by male artists, although women graffiti artists are challenging that male dominance and there are ample examples of their work on social media. The choice of women as subjects dates back to ancient Rome and Greece where idealized female images provided a template for desire, sexuality and goddess status. In modern times, wall artists present women as iconic subjects of power, renewal, and social commentary. Feminine graffiti appears to be idiosyncratic in its subject matter-the product of history, geography, culture and political discourse based on feminine power and influence. Although it is impossible to generalize stylistically about street artists, who are sui generis by their very nature-and wall art defies easy labelling-there are some patterns that are apparent when wandering city streets and encountering women subjects on walls. This photo-essay explores women who feature in wall art in open air galleries in Western Europe, South America and tropical Cuba and seeks to define female archetypes found in these examples. The historical antecedents to modern wall art are presented followed by specific examples of wall art featuring women; succinct interpretations are presented with each example. The journey takes us to Paris, Berlin and Venice, with a stopover in the small fishing town of Huanchaco, Peru, the colourful artistic hill city of Valparaiso, Chile and ends on the worn and tattered streets of tropical Havana, Cuba. In crossing the equator and cultural divide between Western Europe, South America and the Caribbean some surprising trends are suggested in this exploration of women on walls.
\end{abstract}

Keywords: wall art, women in graffiti, city streets, tropical, female archetypes, Europe and South America graffiti 


\section{Introduction: The Evolution of Women on the Wall}

$\mathrm{U}$ rban centres have always provided the street canvasses and personal battlegrounds for graffiti artists to express their hopes, frustrations and rebellion. The graffiti artist often works in the shadows, out of sight of the norms of society, often at night to escape detection so he or she can inscribe forbidden messages and often symbolically subversive images onto public canvases. Graffiti artists may work anonymously but they are rarely neutral in their viewpoints; their aim is to often shock, surprise, delight and colour in grey and shadowy areas of cities. Their visions can be intensely personal, often demanding a new visual vocabulary to interpret outside the framework of existing artwork hanging in museums and galleries.

Women subjects of wall art are as diverse as the artists who portray them, however they often represent a symbolic depth that reaches far beyond the flat surfaces on which they are painted. There are also differences in how women are portrayed in tropical regions-the choice of colours, subject matter, and symbolism vary greatly between the temperate Northern Hemisphere and tropical South America and the Caribbean.

Although this journey focuses on the female subjects of wall art in Western Europe, South American and Cuba, it is helpful to view this public art - still considered vandalism in many cities - in its historical context to give shape to its often obscure meaning.

The personal exploration exemplified in this paper will take you on a virtual tour of wall art of Paris, Berlin, Venice, Valparaiso, Huanchaco and Havana where walls and hidden alcoves can literally elevate the subject matter and surprise us outside the interior-confined world of galleries and museums. In crossing the equator and cultural divide between Western Europe, South America and the Caribbean some surprising trends are suggested in this exploration of women on walls.

\section{The Origins of Wall Art: A Brief History}

The basis of modern wall graffiti, at least in its written form, began at a time in history when women were using walls as a form of hidden communication. Women were actively engaged in sexual graffiti as a form of written communication in ancient Rome (Levin-Richardson, 2013). Female graffiti in Pompeii often involved a description of the act of fellatio; male graffiti was equally explicit. This male boast was discovered in the Pompeiian bar/brothel of Innulus and Pailio: "Weep, you girls. 
My penis has given you up. Now it penetrates men's behinds. Goodbye, wondrous femininity!" (Heaphy, 2017)

If Rome was randy, ancient Greece was subtler when it came to its portrayals of women who were the subject of iconographic ceramic subjects in pottery depicting female desire. Toscano (2013) writes: "Erotic paintings on symposia vases demonstrates that Athenian males took pleasure in the gaze and touch of women while the depiction of goddesses Eos and Aphrodite pursuing their love for mortal men highlight the way these stories acted as cultural signifiers...." (p.2).

Uncovering and decoding ancient Pompeiian sexual graffiti and vase art demonstrates that women have long played a critical role in shaping cultures and societies, expressing eroticism in shape, form and colour, and explicit sexual references on walls - although it is still largely men who are the artisans and writers of graffiti. Graffiti as a form of sub rosa expression of forbidden desire and thoughts outside the legal norms of a society is still a largely male dominated enterprise. If you look at the handwriting on the wall of modern public spaces, the often sharp, angular spray painted typography displays the artist-as-outlaw message which can be an expression of male identity and territoriality (Monto, Machalek \& Anderson, 2013).

Modern graffiti art can trace its start to the late 1960s (Pile, 2017) where it achieved prominence in New York subways as "tagging" or wall writing, which has evolved into ubiquitous bubble letters, street portraits, and murals. But it's more than cryptic writing that has elevated graffiti to art galleries (Dowd, 2017). Certain graffiti artists have achieved international prominence as they evade police, such as the mysterious "Banksy", whose stencilled protest art now sells online as prints. The wall art featured in this exploration also showcases the work of internationally known street artists.

The graffiti artist has long cultivated the image as urban outlaw and graffiti is still considered urban blight that needs to be erased. However, more recently, that perception has changed dramatically despite laws that classify graffiti as vandalism. Graffiti is now thought of as a positive force by some government officials, like London's cultural strategy office which was quoted as calling graffitists pioneers of a new visual art (Cathcart-Keays, 2015). This change in establishment views of graffiti, as enriching the urban landscape, may explain why the women featured in this paper have come out of the graffiti closet and are displayed prominently on public walls. In walking through street galleries, it can be seen how women on walls have been elevated above the debate over the criminalization of graffiti. Wall art featuring women is left alone and it is not considered an eyesore. There are a number of "unknown" wall artists who are depicting women as goddesses, erotic symbols, subjects of political commentary, satire and expressions of national pride and 
culture. The female form has taken graffiti to a new dimension that goes beyond words and into the realm of artistic expression of a new type.

The graffiti artists in the publicity limelight are mostly men. Nevertheless, women street artists have been dipping their brushes for many years now and challenging the predominantly male views expressed on the street (Frank, 2014). Their subject matter ranges from geometric lines based on textiles, to powerful metaphorical beings expressing the feminine psyche, or as one female Parisian street artist paints, grotesque fat men with four eyes. If you Google "Instagram female street artists" there is a large gallery of feminist wall art on display. The women street artists are often working in urban centres like Paris, but it's not just affluent urban centres in the northern hemisphere that attract women artists. The Basotho women in the Free State province of South Africa practice a unique form of graffiti: they paint their mud houses with geometric murals appealing to their ancestors for rain. When the rains come, and wash away the murals, they are replaced the next year (Vanwyk, 1998). This art as an ephemeral, perishable practice embodies the spirit of graffiti art which is now an integral part of human landscapes.

Whether it is a mud house in South Africa, or a wall in Valparaiso, Havana, Paris or Berlin, women have been the inspiration for expressing deeper values in street art, often with a symbolic strength that inspires mythical, iconic imagery and references erotic power. The legacy of this tradition can be found in ancient Greek and Roman societies where women were denied education and positions of power; women in these societies were mostly employed in service trades, and as housekeepers or as prostitutes. Despite their low social status, women were still the inspiration for artists; goddesses walked among the men who carved them out of marble and enshrined them in temple columns, sculpture and pottery.

The images that are explored in this paper are the result of meandering through city streets of Paris, Berlin, Venice, Valparaiso (Chile) Huanchaco (Peru) and Havana and are open to interpretation. As a critical observer, there is a danger of reading too much into a piece of wall art, which can be little more than someone showing off their skills and wit in a clandestine way. However, various female archetypes have emerged from walking the outdoor galleries. Some of the art presented may appear naïve and childlike. Perhaps it is not meant to communicate a deeper meaning or symbol. But when viewed as a whole, the women in this wall art exude an undeniable power - contextually the art may be propaganda, it may be feminist, it may be ambiguous, it may be cultural jamming - but it is rarely dull, and by its very nature is confronting and challenging. The point of view adopted on this tour is one of subjective interpretation in the context of the female form as symbolism. The subject matter is analysed as implied meaning, some of it archetypical, some of it stereotypical. The photographic examples presented in this tour are characterised as 
"wall art" without making specific distinctions between murals, stencilled art, templates, or spray painted pieces. The artists in this journey exhibit a variety of styles and viewpoints and there are two examples of wall artists who have achieved international recognition for their work. All photographs are taken by the authors unless otherwise noted.

\section{Paris Street Gallery}

The celebration of the female form achieved public acceptance in the $19^{\text {th }}$ century Impressionist movement in the salons of Paris. The type of artwork with women as subjects from the tropics can be discovered in the Tahitian canvasses of French Impressionist Paul Gauguin, the highly stylized work of Henri Rousseau, and PierreAuguste Renoir's sumptuous nudes. Given this history of acceptance, Paris retains a sophisticated view of women as wall art subjects.

The country also has a strong revolutionary past reflected in its wall art, which may have reached it height during the student uprising in 1968 when thousands of antiGaullist posters were plastered throughout Paris. Examples of the posters appear in a Pinterest gallery: https://www.pinterest.com.au/gallicabnf/affiches-mai-68-may-68posters/.

The revolutionary spirit of May 1968 witnessed the advent of wall art born in the demolition of one of the city's landmarks, the open air market Les Halles in 1971. Artist Gérard Zltykamien spray painted silhouettes of human figures reminiscent of the shadows of victims of the Hiroshima bombing on the walls of the destroyed building. Another early practitioner of wall art in the early 1970s was Ernest PignonErnest who pasted silkscreen portraits of Arthur Rimbaud around the poet's favourite Parisian haunts (Kostove, 2014). Despite its strong anti-graffiti laws, the revolutionary spirit and tolerance of street art can be found throughout Paris. 


\section{Women as Icons}

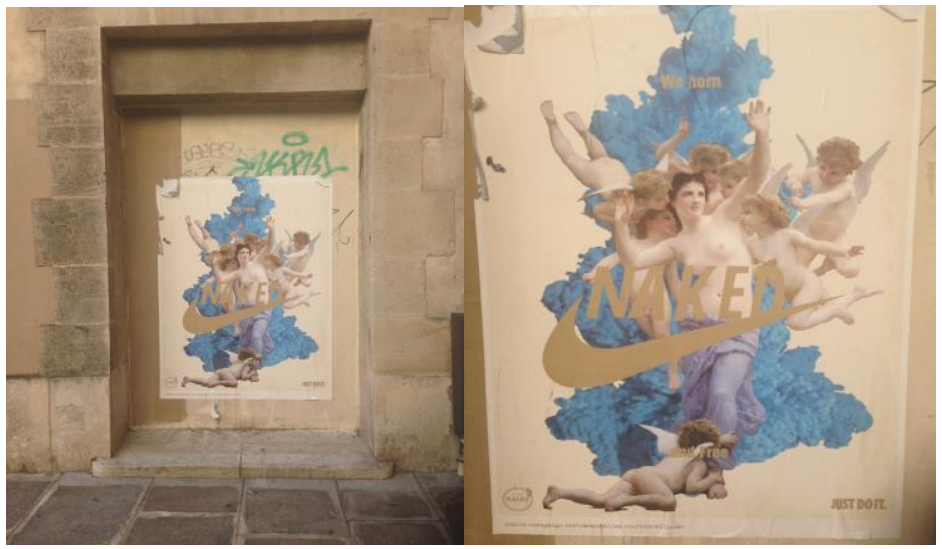

Figure 1. Parisian Nike nude, wall Art by Zalez.

The first example to be discussed, references France's long history of women symbolising freedom on the barricades (Figure 1). This wall art features a reinterpretation of Eugène Delacroix's well known 1830 painting, "Liberty Leading the People". The setting for this art, in a recessed street alcove, reveals the dominance of the French passion for liberty, which is enshrined in their national motto: Liberté, égalité, fraternité. It is also a wry commentary on Nike ads with its logo and tag line: "Just Do It". This piece of art could be considered as a form of cultural jamming, an anti-consumerist movement that takes well known logos and satirises its message. The author of this work is Zalez (http://zalez.fr/artworks/) a male street artist who says he uses female nudes to shock and attract while combining elements of classicism and urban design.

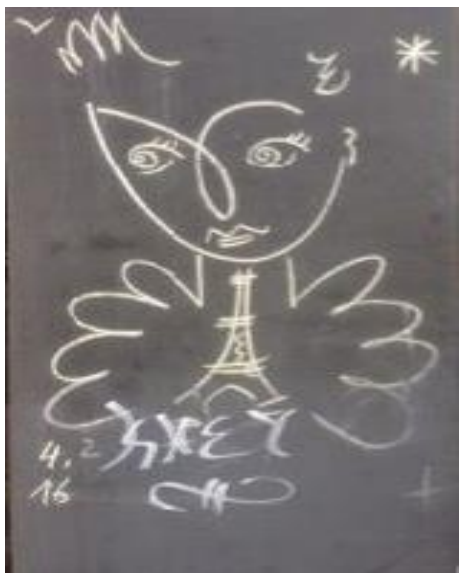

Figure 2. The Parisian female archetype. Photographed by K. Fleischmann, 2018.

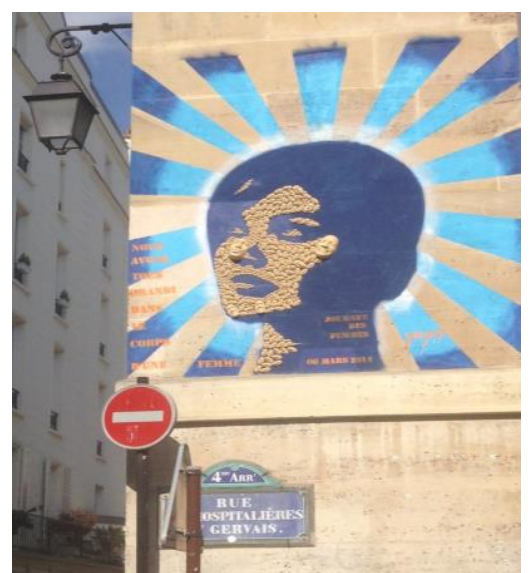

Figure 3. International Women's Day Wall art, Paris, France. Mural by Gregos, 2014. 
In Figures 2 and 3 we can see two re-interpretations of Jungian archetypes: the Lover and Hero. Jung's (1965) pioneering work in dream interpretation defined archetypes based on myths and fairy tales that consistently emerge throughout human history. Stylistically, the wall artist in Figure 2 is taking a page out of Picasso's line drawings in an attempt to re-shape the representation of Paris as a feminine city, not one dominated by Gustave Eiffel's famous phallus built to commemorate the 1889 Universal Exposition. The art in Figure 2 is reminiscent of Picasso's, "Woman and Dove" (1950), a drawing where a woman's face and dove's wing merge. In Figure 2 we see the iconic postcard symbol of Paris, the landmark Eiffel Tower, encompassed by a woman/flower. Paris is often referred to as the city of Light and Love, a city meant for romance, the seductress facet of Jung's Lover. The style in this art is fast, appearing like a chalked image on a restaurant board advertising daily specials. Whatever its purpose, the image of this woman enfolding the Eiffel Tower communicates the power of the feminine dominating a structure which was supposed to be torn down after the 1889 Exposition and is still considered by some women to be an outdated phallic symbol of a patriarchal society. Figure 2 is an illustration that could be interpreted as the new Female archetype of Paris as a city celebrating women.

The mural in Figure 3 was painted by Gregos to commemorate International Women's Day in 2014. Its title bordering the left hand side translates as: "We all grew inside the body of a woman." The mural showcases a woman shining with confidence and power. The rays of light surrounding her head take on an almost venerating, hypnotic quality. Her gaze is confident and challenging, perhaps looking into the future and giving birth to a new age expressed in the mural's tag line. The yellow, fleshy part of the face is made up of face casts of the artist, whose 3D facial signatures can be found throughout Paris and whose work is known internationally. In Carl Jung's Hero archetype (Man and His Symbols, 1964), the woman is able to overcome danger and adversity and the mural depicts that heroic strength, which is now expressed in the \#MeToo movement that is challenging male sexual predation. The artist chose a columnar wall to display the work, which indicates permanence and solidity. 


\section{Women as sexual objects}

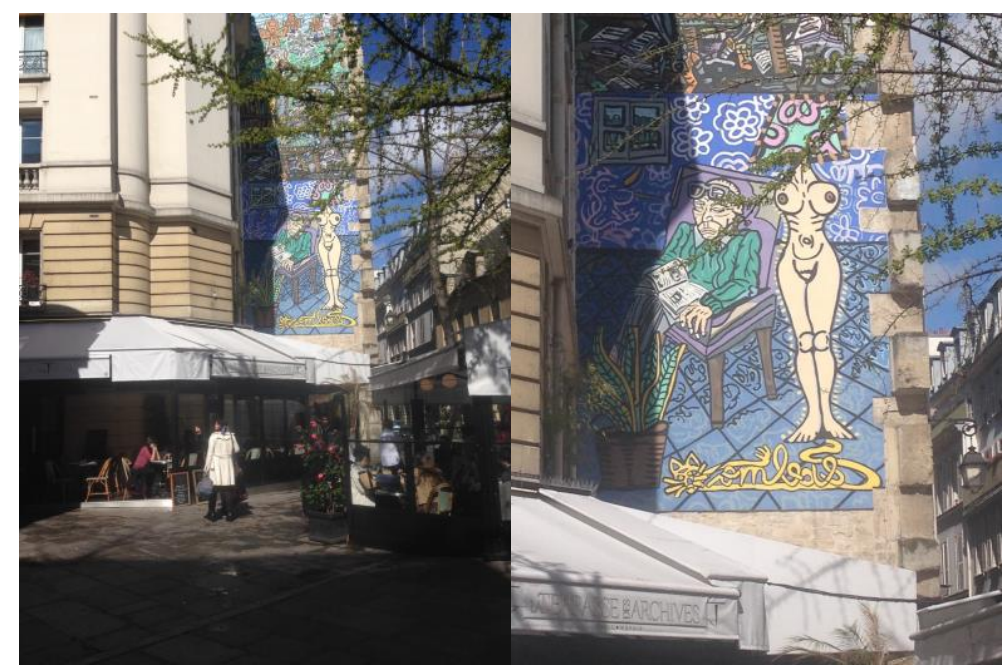

Figure 4. Woman as a lamp next to sleeping man above Parisian café. Photographed by K. Fleischmann.

Figure 4 shows the objectification of the female body which is sharply presented in this large scale wall art above a Parisian café. A man asleep in an easy chair is surrounded by a potted plant and a lamp depicting the exaggerated representation of the feminine body. The woman's head is replaced by a lamp shade and represents the objectification of the female form and elevates this piece to an acerbic social commentary. The archetype of the woman as the sex object of male fantasy is satirized by the man's unawareness in a sleep state. In his dreams, his lounge room lamp may be transformed into his version of a beautiful body he can switch on and off. The artist of this piece is clearly satirizing how unaware men regard femininity, reducing sexuality to an inanimate object.

\section{Dead End in the Marais}

The word in French for dead end is impasse. On the Impasse Saint-Claude in Paris' fabled Marais district, the women on this wall demand your attention. This neighbourhood is well known for its street art and galleries, and this example contrasting four women is strong. On the right of Figure 5a, three women are dancing to their own rhythm and we are watching them in a private moment. These paintings are done in the black and greys of the subdued palette which suggests conformity (see detail Figure 5c). To the left of the dancing women is an erotic, colourful figure, a poster that has been ripped off the wall, presumably because it showed a naked woman. Her breasts and genitalia are gone in what could be the disapproving vandalism of the poster (see detail Figure 5b). The act of graffiti itself is often considered defacing public places, but in this case, it is the wall poster that has 
been defaced in an apparently angry moment. It is difficult to know if the dancing women are a response the erotic poster.

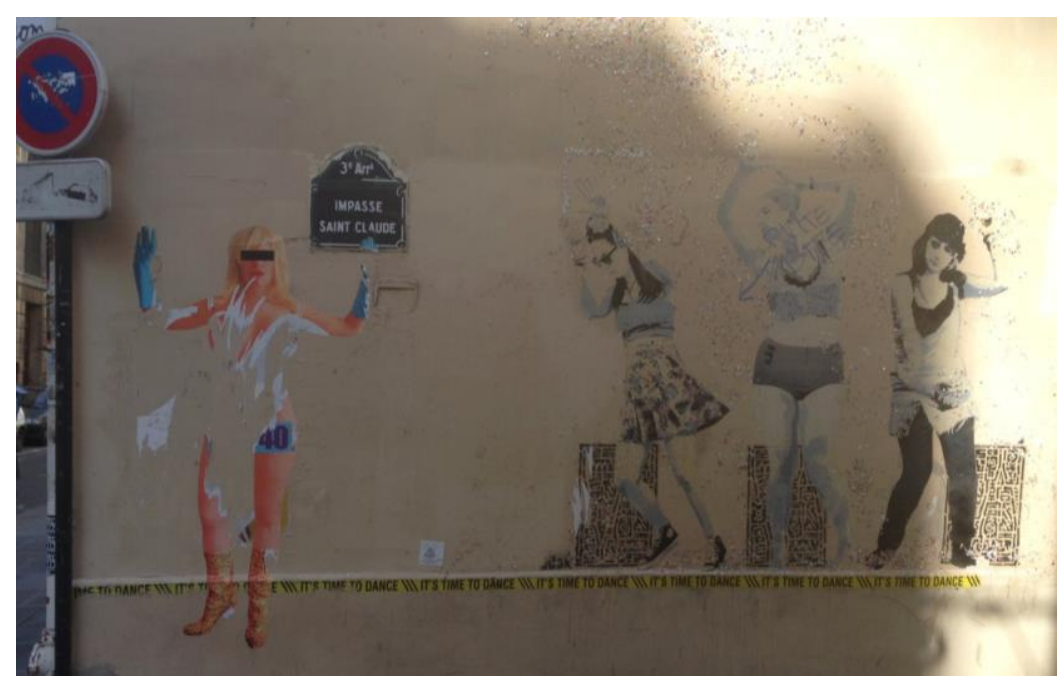

Figure 5a. Erotic surrender and the dancing women, Impasse Saint Claude, Paris, France. Photographed by K. Fleischmann.

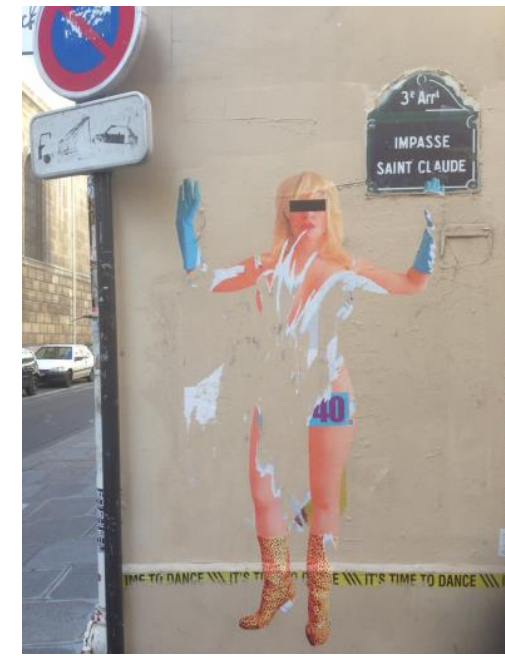

Figure $5 b$. Detail of naked, criminalized erotic woman torn from the wall, Paris, France.

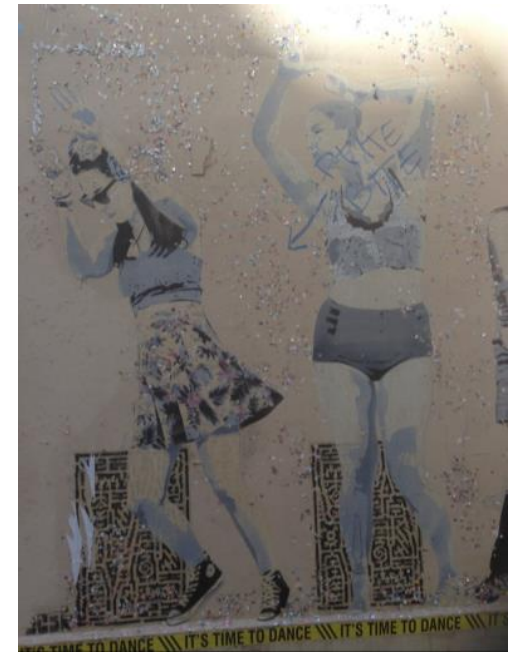

Figure $5 c$. Detail of the street dancers on a dead end Parisian street, Paris, France.

The woman clad in leopard skin boots in Figure $5 \mathrm{~b}$ appears to be wearing blue rubber dish washing gloves, fetishizing her role in the kitchen. Her eyes are obscured by a black line usually signifying an attempt to conceal identity in arrests and criminal proceedings. She has her arms raised in surrender as if she is giving up to authorities. The number on her thigh is a further symbol of objectification, perhaps prostitution. Below all the figures is what looks like police tape from a crime scene, 
but its message is: "It's time to dance", which is what the women on the right side of the wall are doing.

\section{Invader's Wonder Woman}

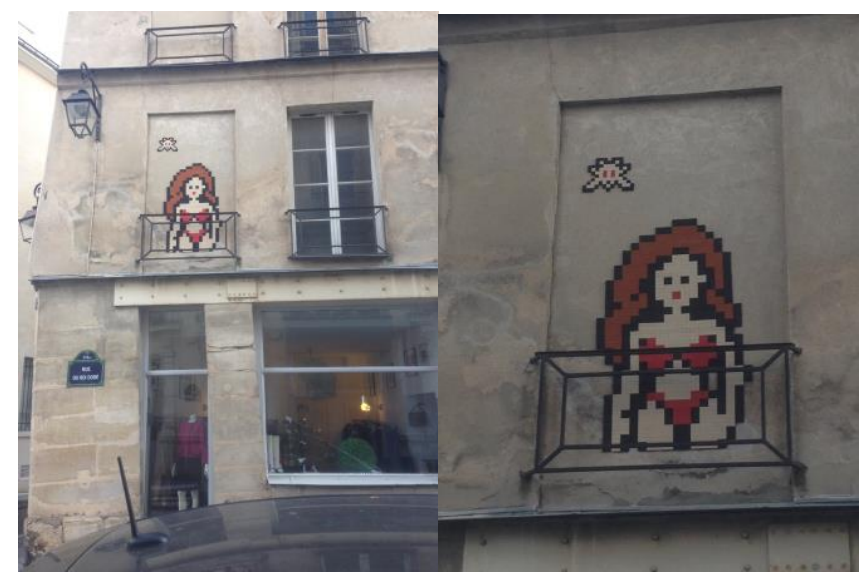

Figure 6. Invader's retro interpretation of the Marvel Comic Heroine, Wonder Woman, Paris, France.

Paris streets feature world famous wall artists. One of them is "Invader", who took his name from the 1978 video game, Space Invaders, which features highly pixilated images. Invader's work can be found globally now. In Paris, one of his works offers us a low-tech look at a woman who embodies the courage of the archetypical Heroine, Marvel Comic's Wonder Woman (Figure 6).

In the recent movie version of the Marvel comic, Wonder Woman hails from a matriarchal island forgotten by the world until a World War 2 pilot crash lands there and discovers a world dominated by strong and courageous mythical Amazon women. In her journey to stop World War 2, the young and naïve Diana morphs into the archetypical Heroine, Wonder Woman, who was recently considered by the United Nations as an honorary ambassador and role model of empowerment for women and young girls. The U.N. scrapped the idea after two months because of widespread objections from feminists who considered the movie version of the heroine as a thinly disguised sex object.

Invader's image of Wonder Woman in Figure 6 hardly looks heroic. It looks like it could be replicated digitally by the billions. In a sense, it dispenses with the entire notion of archetypes in this digital age and looks like it has more to do with building a template for a Leggo version of the Heroine. 


\section{The Existential Woman Walker}

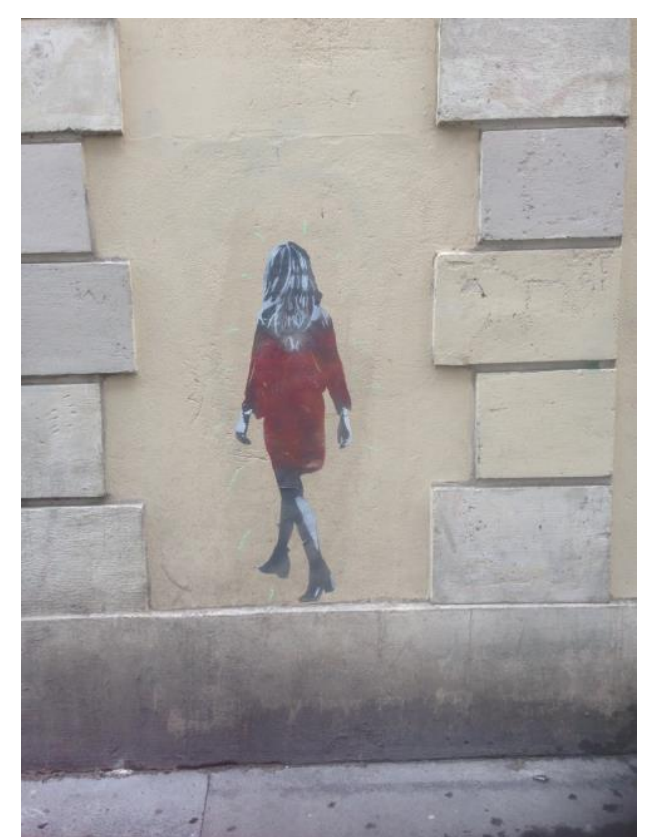

Figure 7. Walking into the unknown in a Parisian wall void.

Paris was home to arguably the most influential existential philosophers in the world: Jean Paul Sartre (awarded the 1964 Nobel Prize in Literature) and Simone de Beauvoir. The two intellectuals had an open sexual relationship and worked on a philosophy that advocated genuine behaviour, not what they saw as the conforming to "bourgeois" values. Beauvoir was a feminist, a woman who was perhaps best known for her 1949 treatise, "The Second Sex," an analysis of women's oppression which became a foundational work for feminism. The influence of these two existentialist philosophers can be seen and felt in the example of wall art in Figure 7.

We see the woman walking into a void, an uncertain future, an uncertain destination. This odyssey requires courage and strength of will, stepping into the unknown - the first act of the Heroine on a journey of discovery which tests her. This woman is alone, her back turned, so we cannot determine what she is feeling. The wall artist's perspective asks us to project our own world of feelings and thoughts onto this figure. This portrait expresses the uniquely French-born existential philosophy, which posits that we walk alone in this world to uncertain destinations.

The figure is striding into a vacant landscape and we will never know what happens. It has a wistful quality not often found in the confrontational street graffiti that is encountered in most urban environments. We are invited to follow her. It is a brave work of art that challenges the idea of the female form as solely an erotic object but possesses a universality that crosses graffiti frontiers and national boundaries 
because it embodies the journeys all people face in life: we enter the world alone and we leave alone.

\section{Venice Gallery}

Venice, Italy is a world heritage city. Its architecture, storied canals, and history date back to 450 AD when it was first settled by people escaping mainland Italy after the fall of the Roman Empire. Over the centuries Venice became an important trading centre during the Middle Ages and Renaissance when its art flourished. Venice is arguably the archetypical city of romance. Walking its narrow streets it is clear why Venice has been called, the "Floating City" and "Queen of the Adriatic".

The water world of Venice may suggest romantic trips on the canals, serenaded by gondoliers, but in reality, Venice is a packed tourist destination sagging under the weight of over-enthusiastic visitors, many of whom go on duty free shopping binges. This jam packed fantasy world, grounded in a preternatural beauty of place and history, full of iconic art, buildings and bridges, is bringing out street protestors as well. While tourists crowd steps to take "selfies" with Venice attractions like the Bridge of Sighs as a backdrop, two thousand Venetians recently staged a protest demanding their lagoon city cater to residents as well as tourists (Edwards, 2017).

\section{The Zombie Shopper}

Wall art can often be interpreted as an act of defiance. Figure 8 is a prime example of protest poster art featuring a bloated "zombie" woman laden with consumerist goods. This satirical image is positioned on a wall overlooking a bridge along one of the city's main waterfront walkways where a steady stream of mainly cruise ship passengers pass by brand name stores competing for their attention.

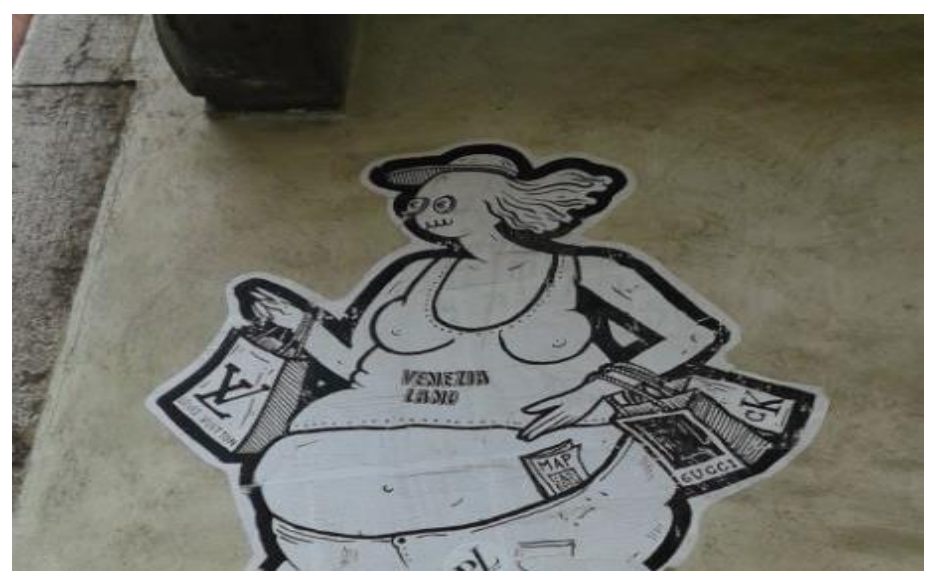

Figure 8. The gluttonous cruise ship passenger, Venice, Italy. 
The image is a caricature accentuating the overconsumption of shoppers - in this case a downmarket woman wearing a singlet with the word Venice emblazoned on the front rendering this historic city as just another brand. A map is shoved into the waist band of her enormous jeans which barely contain her overhanging belly. This "zombie" shopper is emblematic of a growing resentment by Venetians who are protesting that their historic city is becoming overrun with tourists who shuffle past like the walking dead with shopping bags hanging from their arms.

This single image has captured the archetypical tourist as shopper, unaware of the history and beauty that surrounds her, indulging a mindless experience without depth.

\section{Berlin's East Side Gallery}

Of all the cities in the world, Berlin symbolises ideological division and worldwide conflict. The East Side Gallery is an historical artefact of the division between East and West Europe, Capitalism and Socialism. Its very existence is a reminder of the power of wall art to reflect the radical changes brought about by the dissolution of the German Democratic Republic and the collapse of the Eastern Bloc, once dominated by Russian ideological hegemony.

The East Side Gallery forms a fragmentary history of a city divided by political systems, given concrete expression by a razor-wire topped wall. The Berlin Wall graffiti featured in the East Side Gallery was created in 1990 after the wall fell. The gallery expresses symbols of the hope, despair, and eventual unity of the divided world where street art sharply focused political power in its imagery.

\section{Eve as Pagan Tropical Goddess}

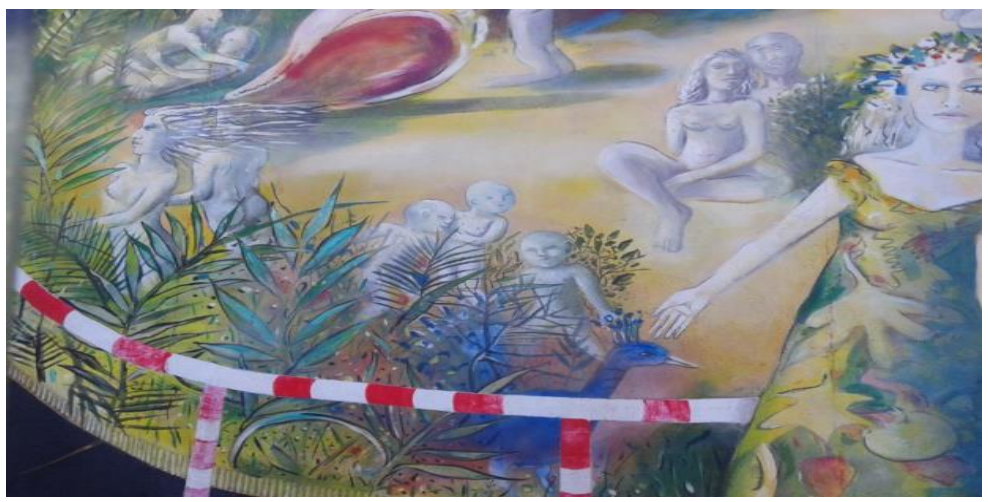

Figure 9. The New Eden, East Side Gallery, Berlin. 
This metaphorical fragment from the remains of the Berlin Wall in the East Side Gallery (Figure 9) suggests a world beyond the wall, where men and women can freely become lovers and wander in a garden of delights. It is an Edenic vision in a tropical setting - dominated by a woman welcoming the viewer with open arms. She wears a dress symbolising nature, a blue peacock wanders the foreground, surrounded by a landscape of broad-leaved and palm-frond plants. The wall art in Figure 9 brings to mind the natural innocence found in Henri Rousseau's naïve paintings with a colour palette and subject matter inspired by Marc Chagall. The dream like figures float above the central female figure who is the progenitor of a new beginning. We see a naked couple embodying a natural unity, naked children play in this colourful landscape, in the upper left a couple makes love next to a floating womb, symbolic of a re-birth. The graffiti strongly suggests the Garden of Eden stripped of its Old Testament religious references. The do-not-cross barrier stands between the woman and the earthly delights that lie beyond. The barrier is symbolic of the wall, but in this example it would be easy to cross. The graffiti may be representing an idealized vision of the West as imagined by those living in the German Democratic Republic.

\section{The Mouth That Shouts}

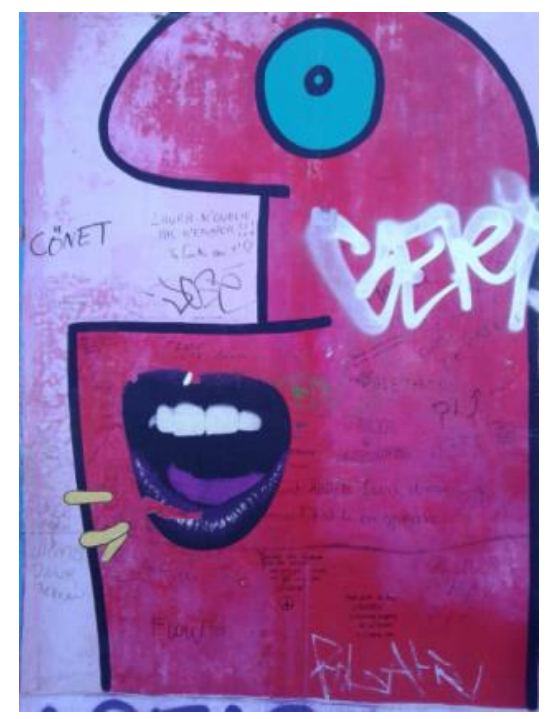

Figure 10. A woman's photo-realistic mouth inside a frozen, purple cartoon man by T. Noir, Berlin.

This example from French street artist, Thierry Noir, is part of the protest art he painted on the Berlin Wall over five years. Noir scavenged paint from building sites with the aim of painting the wall quickly with his cartoon profiles - a fast style born from his having to avoid East German border guards. Noir claimed to be the first 
street artist to paint the Berlin Wall and his work is symbolic of protest over the wall's divisions.

The concrete barrier that was the Berlin Wall demarcated two systems of government and economics but also served as a barrier to political dissent in its rigid structure. That rigidity was given a face in Noir's purple, cartoon countenance which features a realistic female mouth that is openly defiant (Figure 10). The head is reminiscent of an immobile stone statue, with a vacant stare. But the power, depth and dimensionality come from that dark-lipsticked mouth, which appears to be a stylistic afterthought that could have been added at a later date. We are unsure of the message, but it certainly suggests a hidden power when a woman's speech enters the frozen picture. And this woman is speaking loudly and with purpose.

\section{South American Street Artists from Chile and Peru: Colour of the Tropics Informs Art and its Feminine Symbols}

A different artistic sensibility colours the street art depicting women when you cross the equator into South America. The colours are brighter and reflect the tropics as do the shapes and patterns in the art. The equatorial buffer zone between Northern and Southern hemispheres is also a cultural one. The countries of South America mix indigenous animist and pantheistic beliefs with the religion of their Spanish and Portuguese colonisers. Where protest and social commentary wall art predominate on the streets of Paris, Berlin and Venice, the South America examples presented on this journey represent an historical and cultural shift in the depiction of women who live closer to archetypes from pre-Colombian cultures. Even with different artistic sensibilities at play, the South American women on walls share the rebellious spirit with their northern hemisphere counterparts. Born from patriarchal societies that venerate Catholic priests, the bright tropical colours and subject matter speak to a world where women are the flowing river beneath the vestments of male dominated societies. The subject matter is rarely confronting in these examples but they communicate a quiet shamanistic power.

In this next section we walk the streets of Valparaiso, the artistic Chilean city on the coast near Santiago where Pablo Neruda once wrote his sensual poetry overlooking the rocky, cold and wild Pacific. Then we will stroll the street galleries in the small Peruvian beachside town of Huanchaco, Peru, a fishing village and home to an active surf culture. As will be seen, there are definite connections to feminine symbols and archetypes that cross the equator. 


\section{Valparaiso Street Gallery}

The very name of this famous port city conjures up sensuality, with its colourfully painted homes cascading from steep coastal mountains and valleys into the streets below. There is a salty tang in the air from the foggy, cold Pacific Ocean waters, giving an edgy feel to the streets. Much of the art is found in the hills above the port where portraits of women watch over the narrow streets projecting a mysterious hold on the city.

\section{Women as Muse and Mother}

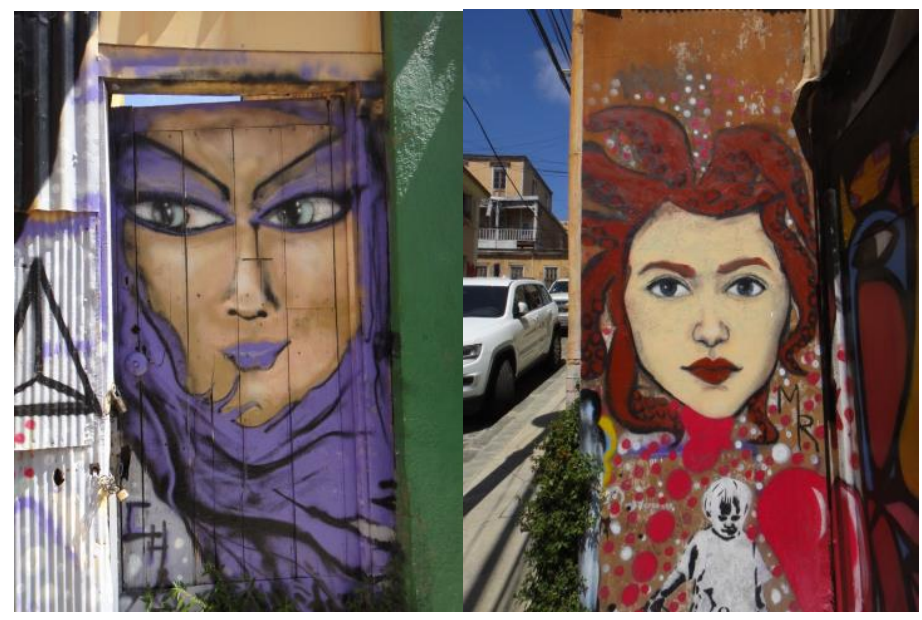

Figures 11 and 12. The eyes of mysterious women watch over Valparaiso, Chile's hilly back streets.

When viewing street art, spectators must use a new visual vocabulary that requires close examination. Two examples presented in Figures 11 and 12 illustrate this point. In Figure 11 ambiguity informs the purple portrait while in Figure 12 there are symbolic references to Greek mythology.

On the surface, the women in purple in Figure 11 does not reveal a great deal. Her blue, penetrating Siamese cat eyes contrast sharply with her purple scarf which swathes her head; her lips are also purple and form a sly, street Madonna smile. The image is open to multiple meanings; it is unclear what the artists intends, however the bright colour will bring personal associations to the viewer. The ambiguity of the subject gives this portrait its quiet strength. The portrait in Figure 12, by contrast, is full of symbolic references. The woman's red hair forms tentacles, suggesting a connection with the biological Medusozoa (jellyfish) named after Medusa, the mythological being who turned people who stared at her to stone. The ocean is also evoked in this portrait; Valparaiso perches on the Pacific, where octopi swim among the rocks and appear on dinner plates. However, the woman's face resonates with 
kindness and the intimate influences of Gustav Klimt and the child below seems protected by her presence. The child is a completely different style of artwork, but when taken as whole, the association of the mother/child bond cannot be ignored in this portrait.

\section{The Defiant Gesture}

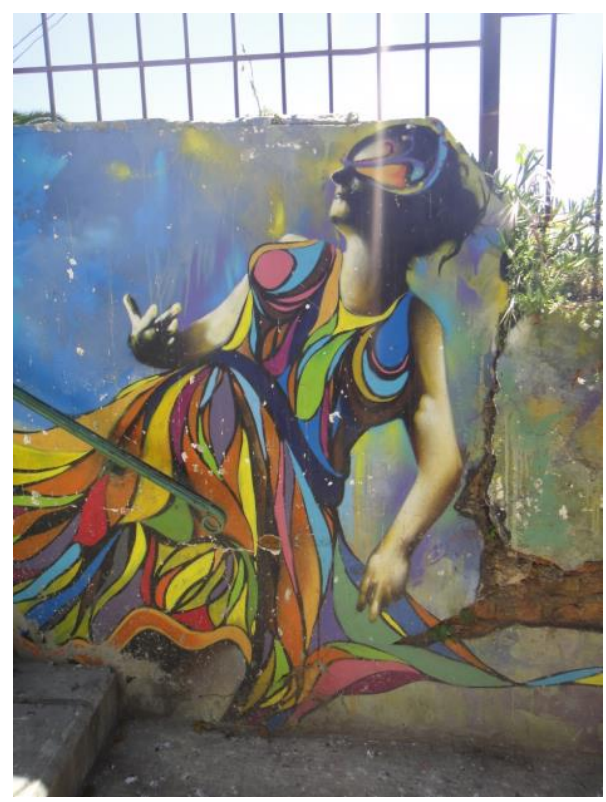

Figure 13. A street stairway frames an energetic and defiant woman in Valparaiso, Chile.

This dramatic, dynamic work of street art in Figure 13 suggests the subject has been pushed down a stairway. Street portraits often use public constructs, like stairways or alcoves, to form part of the artistic framework and backdrop. This gives the artist an unconstrained dimensionality not found in framed works, allowing the piece to border on street theatre.

The interpretive clue of this stairway is difficult to see but is found in the gesture of her right hand. Here we see what is clearly an act of defiance. The subject's right hand appears to be forming the "fuck you" gesturing of "the finger". She is looking straight at her attacker who presumably stands at the top of the stairs but the strange mask covering her eyes does not reveal her state of mind. It forces the viewer to focus on her hand and her posture turning back to confront her apparent attacker. The bright colours of her flowing dress evoke a protective, rainbow shield and tropical foliage. The viewer is witnessing a warrior-like strength in the face of adversity, a re-imagining of the Heroine archetype who must overcome challenges by often fighting stronger powers on her quest for self-enlightenment. 


\section{Sexual Liberation}

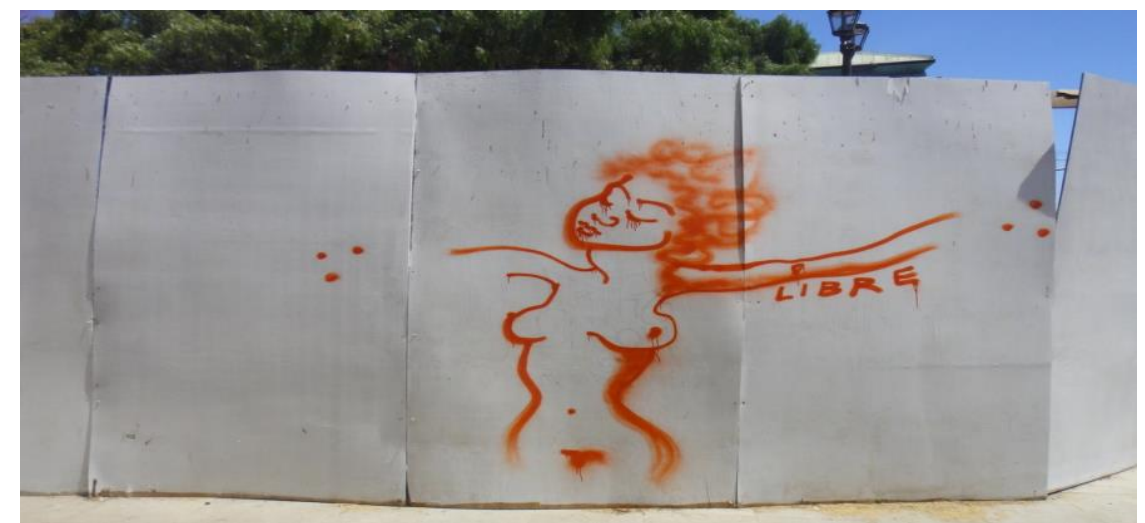

Figure 14. Uninhibited sexuality on display in a hasty line drawing in Valparaiso, Chile.

South America is a multi-racial melting pot that has integrated African influences from slaves who were brought there to work at the height of colonial domination. Millions of Africans were transported to Spanish, French, and Portuguese colonies and forced to work in sugar cane fields and silver and gold mines. The historical influence of this slavery informs this street art of a woman who has the features of a black woman (Figure 14). Its message, therefore, conveys a double meaning.

This unabashedly sensual spray painted line drawing celebrates female sexuality and even drops a very strong written hint about how this piece should be interpreted: "Libre" means "free". And this street art celebrates a woman's sensual freedom to stand naked to the world with confidence, and perhaps also freedom from slavery.

\section{The Next Generation Girls}
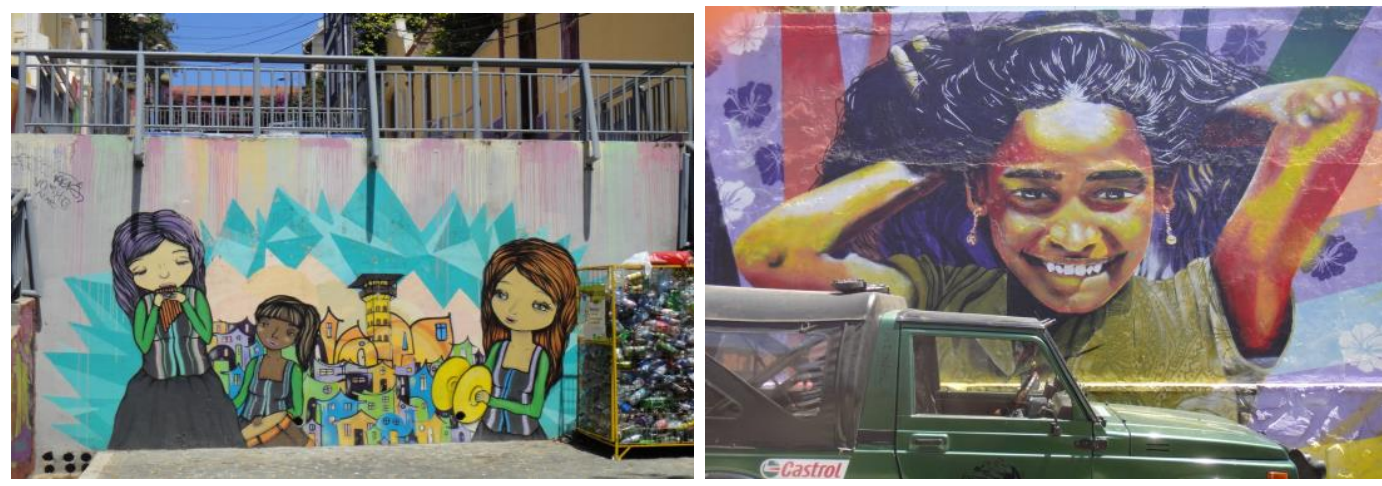

Figures 15 and 16. In Valparaiso, Chile, wall art featuring young girls provides a window onto the future and a way to brighten urban landscapes. 
A city's future is closely bonded with youth who give energy to its streets, particularly young women starting on life's often precarious journey of self-discovery. Figures 15 and 16 celebrate this youthful energy embodied by young girls. Chile is a society with a strong tradition of musical instruction in schools. This portrait of girls learning to play music together in Figure 15 has a naïve, cartoon quality that matches the first steps toward learning to play instruments; the scene is a strong symbol of education in a country that values artistic expression but also has a history of cracking down on dissent where street art formed the artist expression of rebellion. On the right is a much more representational photo-realist work of a young girl revelling in her youth (Figure 16). Her smile captures her delight in the moment as she runs her hands through her hair. There is a playfulness in her movement which has not been corrupted by age and cynicism. Both pictures take a different approach to the developing women inside the girls, one didactic, the other expressing the pure joy of being young and alive.

Obstacles are around every corner in urban environments. Figure 15's urban context, next to a recycling container, provides a growing example of how wall art is now being accepted as a way of adding colour, movement and social messages to cities coping with waste and decaying streets.

\section{The Indian Woman of the Altiplano}

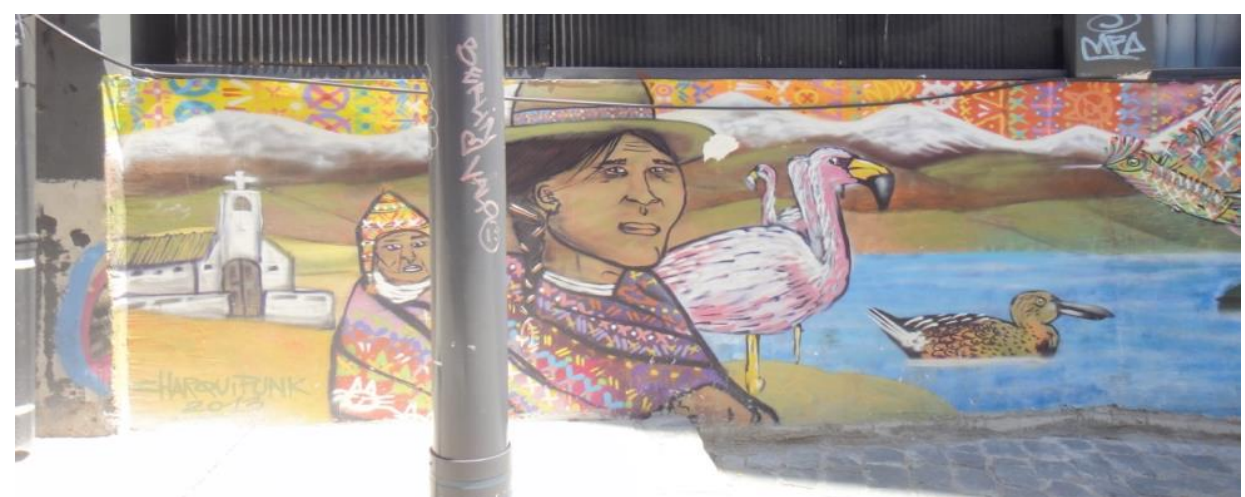

Figure 17. Portrait of the indigenous people and birds of the Andes with the omnipresent Catholic Church in the background, Valparaiso, Chile.

Northern Chile is home to indigenous women who live at the base of the Andes. The world of the Altiplano is a starkly beautiful high desert dominated by volcanoes which tower above the moonscape. This high plain features some of the driest places on earth, especially around Lake Titicaca which straddles the border between Peru and Bolivia. Flamingos filter the ephemeral waters of the Altiplano's salt lakes; below are the lush tropical jungles which gird South America where toucans fly among the giant trees. In this portrait (Figure 17) we see an archetypical indigenous woman of the 
Altiplano wearing her traditional bowler hat and shawl overlooking a lake with pink flamingos and a shovel nose duck. Her face and that of her companion reflect the cold, dry world where she lives. In the background is a church, the symbol of the colonisation, conquest and conversion of the indigenous peoples of remote parts of South America. It is a reminder of the reach of the colonial powers which shaped the culture and history of South America. There is no obvious point of view in this wall art; it is more of a pictorial representation of history, geography and Altiplano people.

\section{Huanchaco: Peru's Dry Tropical Beach Town}

Peru's Andes preside over one of the main tributaries of the Amazon River. The jungle is born from the headwaters of Peru's Mantaro River. There are also drier regions along Peru's coastline that border the tropics. One of them is Huanchacho, a beachside resort in north-western Peru near the Chan Chan ruins and Trujillo. It is a dry tropical landscape, a town known for its fishing and surf breaks and quiet streets-and a surprisingly wide variety of vibrant street art depicting women.

\section{The Indigenous Sorceress}

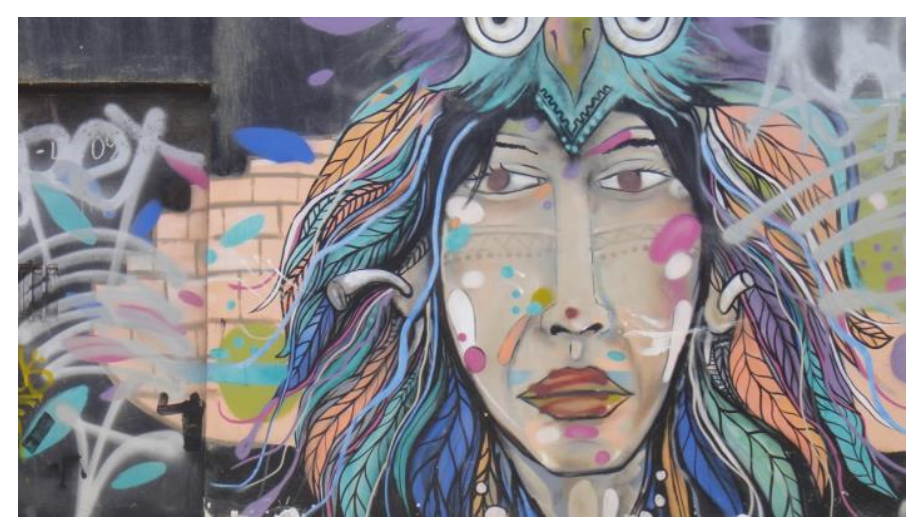

Figure 18. Animist priestess, Huanchaco, Peru, cloaked in an owl's spirit.

Ancient cultures often used animals as a point of reference to express the many facets of personality and belief systems. In this modern animist interpretation (Figure 18) the Owl headdress features prominently. In Peru, the owl is a symbol of good fortune and death. The belief is that if an owl lands on the roof of a person's home and starts singing then someone in the home will die. The owl also brings wisdom. As an archetype, this woman symbolises the power of the owl in Andean mythology. This powerful woman can bring death or good fortune. She is also adorned in what appears to be leaves and feathers, and her ears are pierced with bones. She could be the archetypical indigenous sorceress who has tapped into the power of nature. 


\section{Through the Portal}

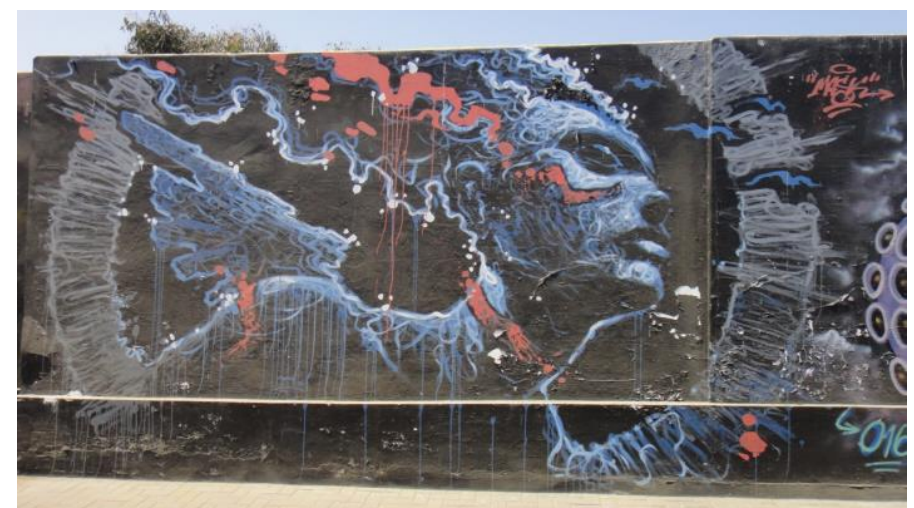

Figure 19. The cyber Heroine entering a digital portal, Huanchaco, Peru.

The portrait in Figure 19 crackles with energy and symbolism. On close viewing it appears to be a neotribal woman entering what looks like a cyber portal. The subject is in the process of transformation, but the viewer can only guess what that process will yield. Her hair has become wild electronic streams. The artwork has a frantic energy and dreamlike quality, lacking clear definition or outcome. The woman, however, is facing forward and is unafraid of what is about to happen and she walks through the portal. She could be a cyber Heroine, entering a new digital realm or phase. This wall art is a re-imagining of the archetypical journey of self-discovery. Whether intentional or not, the women in this work also references an iconic Grade B horror movie, "The Bride of Frankenstein" who was stitched together by a mad scientist trying to control nature.

\section{The Plugged In Digiphile}

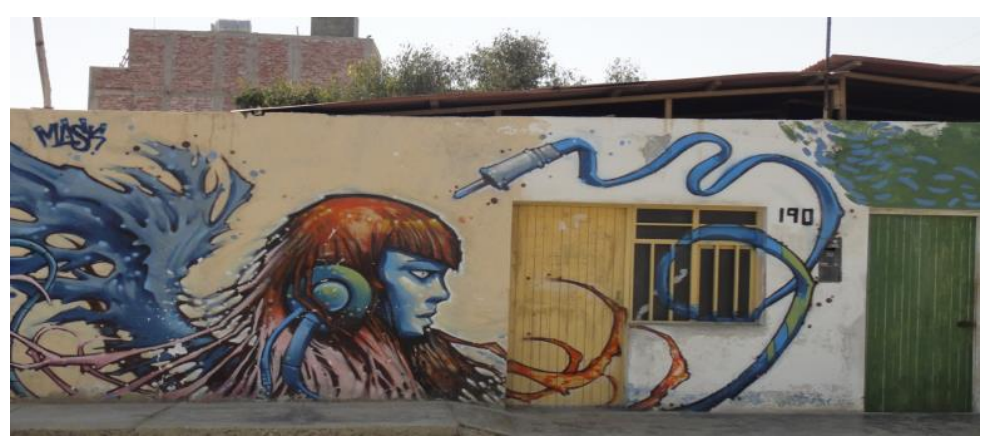

Figure 20. The mythical digiphile woman is indicative of a new plugged in archetype, Huanchaco, Peru.

There are new ways to create mythical beings and the artist of Figure 20 has created a Griffin-like woman for the digital age. Blue wings sprout from her back, while on the right side of her body emerge spider-like appendages. Her tail is a snaking digital 
cable; while her ears are covered by headphones, which are presumably pumping in music that has her transfixed. The young woman's blue face is frozen in a hypnotic stare and she appears lost in whatever she is listening to. In creating this new archetype for the digital age, the artist has borrowed and updated medieval symbolism. The plugged in digiphile mythological woman pictured in Figure 20 is a visual commentary on the relationship between digital devices and the mind and persona. She is clearly representative of young women who are transformed by their digital devices.

\section{Cuba's Street Art: Tropical Commentary in a Socialist Bubble}

We end this exploration in Havana, Cuba, a city that conjures up a pre-revolutionary vision of extravagance and corruption in the Caribbean. It is a city where American mobsters used to come and gamble, a city flourishing brothels and leggy showgirls dancing the mambo. During the Cold War, Cuba was the centrepiece of a nuclear showdown between then Soviet premier Nikita Khrushchev and the young U.S. President John F. Kennedy. The world watched and waited to see who would back down first. Nuclear war was averted when the Russians withdrew their missiles.

Cuba during the missile crisis was in the firm grip of Communist leader Fidel Castro who was the target of failed CIA assassination plots. In this cauldron of intrigue and revolution, wall art was a tool for political propaganda when Communism was perceived as a real threat in the West. The footprints of the past can still be found in the rundown glory of this tropical version of a Communist state in transition. Havana maintains a shabby chic among world travellers wanting to sample the island's legendary music - salsa, son, cha-cha, mambo and rhumba - and walk among its socialist ruins. Nowadays, big restored American cars from the 1950s and 1960s motor tourists around Havana's waterfront and pass by government buildings and walls that feature portraits of heroic Communist revolutionary men. Perhaps the most widely produced image is that of Che Guevara (Figure 21).

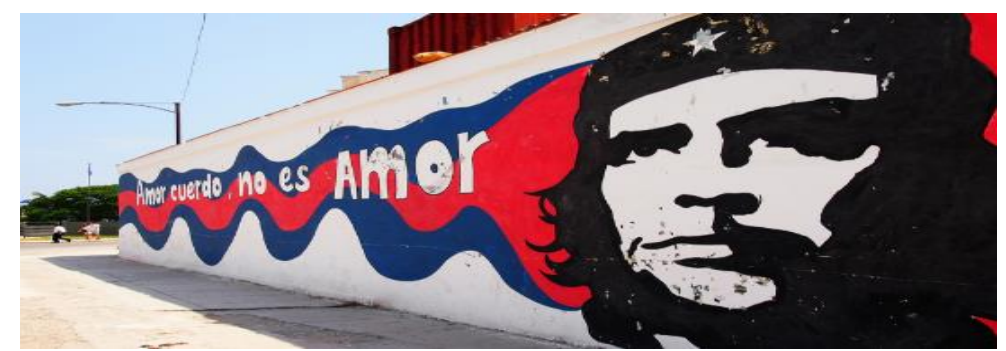

Figure 21. The ubiquitous image of revolutionary Hero Che Guevara, next to quote by Cuban poet, José Martí, "Sane love is not love." https://www.flickr.com/photos/kudumomo/7277571478 


\section{Havana's Missing Women}

Havana's women on walls are not commonly found. In the realm of government sanctioned propaganda, male revolutionary war heroes feature prominently. However, wall artists critical of the Cuban government are starting to appear from the cracks in the dilapidated buildings, and some of their wall art includes women.

Cuba is experiencing a makeover born from an incremental liberalization of the economy connected to the outside world by the internet and the lifting of economic sanctions, although the country is still held hostage to fuel shortages by the economic crisis in Venezuela, its main petrol supplier.

A new ethos and young artists are breaking state-sponsored propaganda. Graffiti is an emerging art form in Cuba. The street artist's colour palette is largely subdued, black-and-white-and-grey which reflect the often decrepit buildings and sidewalks of old Havana, and perhaps a lack of art supplies. The new Havana graffiti artists are turning to abstract symbolism to critique lives where speaking out can land you in jail. It is interesting that females are largely absent in the new protest wall art in Cuba and only a few images of women were encountered.

\section{Driving by the Revolution: Emerging Revolutionary Images}

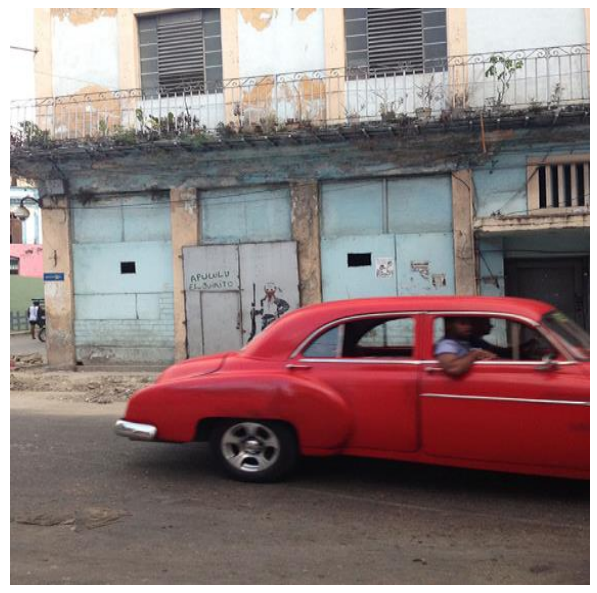

Figure 22. Old American car driving by the stencilled revolutionary, Havana, Cuba.

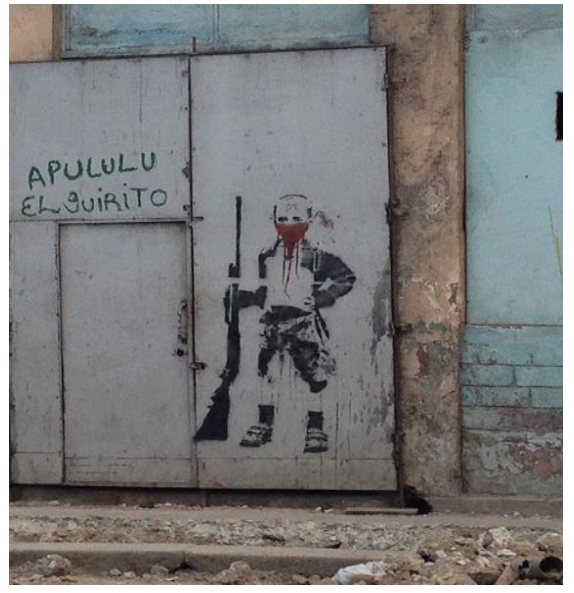

Figure 23. The stencilled revolutionary.

Men still take centre stage in Cuba's state-sponsored street art as revolutionary heroes. This iconic image of an urban street fighter may be stencilled. It stands guard over a crumbling sidewalk. The only colour - red - is dripping from the handkerchief concealing the street fighter's identity. This could be a critique of socialist realism, or symbolic of revolutionary vigilance on the street. 


\section{Censorship's Progeny}

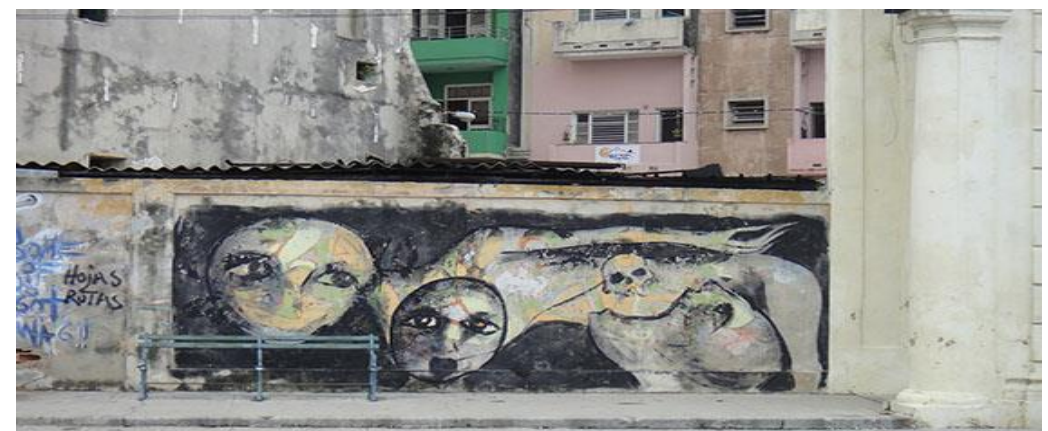

Figure 24. An example of Havana's new street art, by Y. Rodriguez.

Figure 24 is probably the work of Yulier Rodriquez who paints mouthless beings as a comment on censorship in Cuba (Marsh, 2017). Rodriguez is one of the Havana's new street artists who is using wall art to push his protests; the colour palette of this wall art is subdued like the rundown streets which gave birth to its aesthetic. Out of the mouth of one face a skull is ejected; on another face a woman's lips are sealed. The Cuban regime has stifled dissent by arresting critics and gays. The government still keeps a tight grip on internet access, actively censors internet sites critical of the government, and controls all major media.

\section{Looking Ahead}

This surreal mural in Figure 25 has a dreamlike quality that offers the viewer an original vision with little obvious reference to outside artistic influences. The subjects are half hidden; partial faces emerging and connecting. The half-face of a woman appears on the right hand side of the painting. A ladder forms a symbolic bridge between the subjects. This is abstract art which appears to be a symbolic of a new way of thinking and connecting.

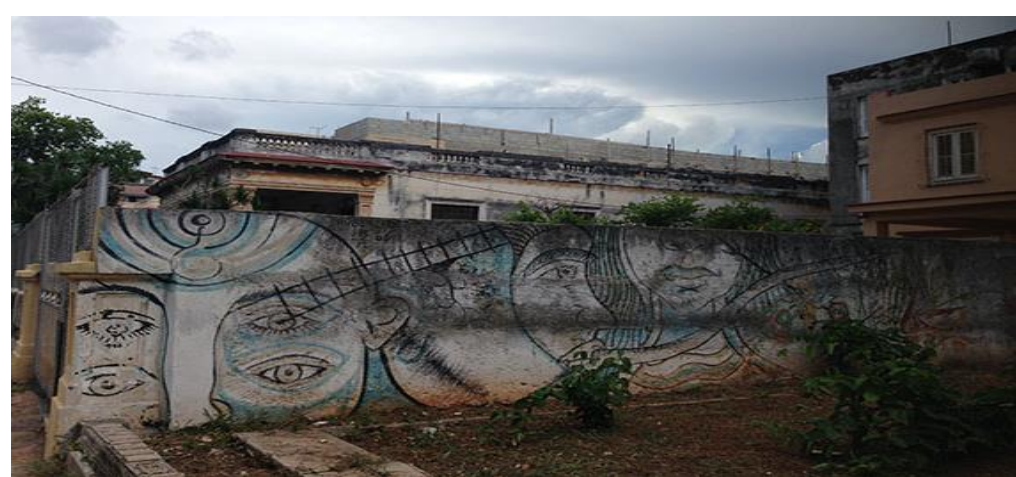

Figure 25. An open vision bridging isolated people. Havana, Cuba. 


\section{Klue Slor}

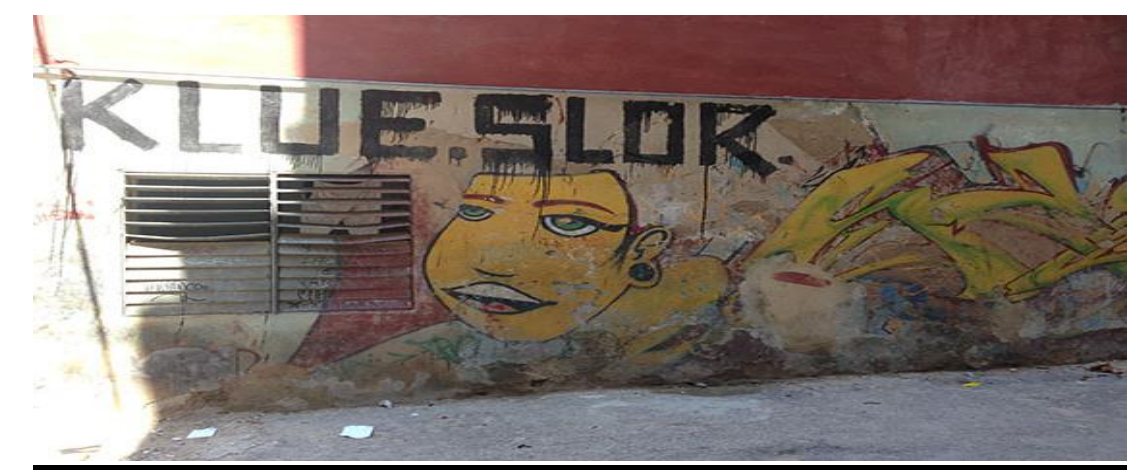

Figure 26. A street tag, "KLUE SLOR" dominates one of the few women featured on a walk-through, Havana, Cuba.

This wall features a Cuban woman - one of the few encountered - under a tag, "KLUE SLOR" (Figure 26). The tag's meaning may be nonsense to an outside observer. The image is equally void of any immediate visual references or clues other than the woman's Afro-Cuban features. The art could have a local Havana reference. This is a case where a woman on the wall could just be an energetic street decoration, perhaps even a local club or even a street boundary. At times wall art visual codes cannot be cracked unless the observer knows the exact details of how it was created.

The back streets of Havana are rundown. Many waterfront apartments along the city's Malecón waterfront promenade resemble rotting teeth. When a person walks along these streets, encounters with wall art like KLUE SLOR are unusual and may simply indicate an attempt to brighten the urban decay. This is a country were buying paint to decorate walls is subject to severe shortages or unaffordable to your average Cuban. Out of the ruins of Havana emerge a city full of visual surprises, full of the heritage of its African roots: home to salsa, son, rhumba and cha-cha, it is a country that above all else pulsates to its own Afro-Cuban beat.

\section{The Gallery That Never Ends}

Graffiti art has adorned the walls of our cities for centuries. In the hands of some artists, graffiti is an act of subversion, a personal stamp on an impersonal world. This rebellion is often found in male dominated written graffiti with its coded messages defiantly marking territory like dogs urinating on lampposts. But it was the women of ancient Rome who were discussing explicit sex on the walls of Pompeii. In all cases, historical context and place informs the choices of subjects and symbols in wall art depicting women. 
Illuminating our often bleak landscapes marked by almost illegible scrawls, neon colours, or representational art, and subdued hues, are the women of the walls the eternal female presence who elevates public artistic expression to new levels in our cloistered, digital world. In the Western Europe cities discovered in this journey, the women on walls are often symbolic of political debate, veneration, satire, and self-discovery as they dance to their own rhythms and embark on personal journeys. In the Peru and Chile wall art explorations, artists painting women on walls take a different visual approach. Their subjects often reference the rich indigenous cultures of South American and the central role women play as they challenge the traditional patriarchal societies. Women on these walls are presented as powerful priestesses in an electronic age and animists, with references to the tropics in their adornments.

In Cuba, in the heart of the tropics, the wall art scene has ample examples of government sponsored propaganda on walls and buildings, which feature Cuba's revolutionary men, the ubiquitous portraits of Che Guevara, Fidel Castro and Camilo Cienfuegos. Women revolutionaries rarely appear in this pantheon. Working quietly in the background are emerging Havana protest artists like Yulier Rodriguez who embodies the rebellious, clandestine spirit of wall artists globally with his abstract women and abstract beings without mouths, a powerful visual comment on Cuban censorship.

Whether it is an adornment on a Greek vase, a column in a marble temple, or secret handwriting on a wall, women have for centuries occupied centre stage as subjects in public art. The feminization of wall art empowers any artist, male or female, to take symbolic chances. The women on walls often reveal themselves as subtle acts of defiance and exposition. They can be archetypes of a rebellious spirit. The female subjects on this tour celebrate the feminine psyche in its various guises and shapes: the Heroine, the Priestess, the Lover and Seductress are all represented in these random samples of wall art.

As spectators, we are challenged to stop and look at these public images because they demand our attention. The women in this wall art are a prism to focus our thoughts on what it means to be a woman in today's world. Our tour of open air galleries revealed images of powerful women who are iconic, women who are expressing their sexuality, women who wear disguises and others who express the ideals of freedom. We have seen various interpretations of young girls, who may grow into the leaders of our world. Whoever the artist is, or wherever they paint, the women on the wall are keeping an unspoken watch over us. 


\section{References}

Cathcart-Keays, A. (2015). Is urban graffiti a force for good or evil? The Guardian. Retrieved from https://www.theguardian.com/cities/2015/jan/07/urban-graffiti-force-good-evil de Beauvoir, S. (1949). The Second Sex (Le Deuxième Sexe). France: Gallimard.

Dowd, V. (2017). Jean-Michel Basquiat: The neglected genius. BBC News, 25 September 2017.

Edwards, C. (2017). Venice residents protest against tourist influx. The Local lit. Retrieved from https://www.thelocal.it/20170703/venice-residents-protest-against-tourist-influxmass-tourism-mi-no-vado-via

Frank, P. (2014). 10 Women Street Artists Who Are Better Than Banksy. The Huffington Post.

Heaphy, L. (2017). THE BAWDY GRAFFITI OF POMPEII AND HERCULANEUM. Kasghar.

Kostov, A. B. (2014). History of Street Art in France: A Quick Overview. Widewalls: Graffiti \& Street Art. Retrieved from https://www.widewalls.ch/history-of-street-art-in-france/

Jung, C. G. (1965). Memories, Dreams, Reflections. New York: Random House.

Levin-Richardson, S. (2013). FEMALE SUBJECTIVITY AND AGENCY IN POMPEIAN SEXUAL GRAFFITI. The Classical Journal, 108(3), 319-345.

Marsh, S. (2017). Cuban graffiti artists bring social critique to Havana's walls. Reuters. Retrieved from https://www.reuters.com/article/us-cuba-graffiti/cuban-graffiti-artistsbring-social-critique-to-havanas-walls-idUSKBN1AP1C9

Monto, M. A., Machalek, J., \& Anderson, T. L. (2012). Boys Doing Art: The Construction of Outlaw Masculinity in a Portland, Oregon, Graffiti Crew. Journal of Contemporary Ethnography, 42(3), 259-290.

Pile, J. (2017). A Brief Guide to The Evolution of Graffiti. Short List. Retrieved from ShortList website: https://www.shortlist.com/news/the-evolution-of-graffiti/51193

Toscano, M. M. (2013). The Eyes Have It: Female Desire on Attic Greek Vases. Arethusa, 46(1), 1-40. doi:https://doi.org/10.1353/are.2013.0002

Vanwyk, G. N. (1998). The Mural Art of Basotho Women. African Arts, 31(3, Summer, 1998), 58-65. 